ographic assessment of left ventricular performance in normal newborns. (irculation, 49: $232(1974)$

47. Sahn, 1). J., Terry, R., O'Rourke, R., Leopold, G.. and Friedman, W. F.: Multiple crystal echocardiographic evaluation of endecardial cushion defect. (irculation, 50: $25(1974)$.

48. Salun, D. J., Terry, R., ORourke, R., Leopold, G., and Friedman, W. F.: Multiple crystal cross-sectional echocardiography in the diagnosis of cyanotic congenital heart disease. (irculation, 50: 230)(1974)

49. Sahn, D. J., Vaucher, Y., Williams, D. 1.., Allen, H. D., Goldberg, S. J., and Friedman, W. F.: Echocardiographic detection of large left-to-right shunts and cardiomyopathies in infants and children. Amer. J. Cardiol. .38: 73 (1976).

50. Sahn, D. J., Vaucher, Y., Williams, D. E., and Friedman, W. F.: Ficho distinction of left-to-right shunts from nen-structural heart discase (NID) in infancy. Circulation. 50: $16(1974)$.

51. Sahn, D. J., Williams, D. E.. Shackelton, S., and Fricdman, W. F.: The validity of structure identification for cross-section echocardiography. J. Clin. Ultrasound, 2: $201(1974)$.

52. Scward, J. B. Tajik, A. J., Spangler, J. G., and Ritter, I). G.: Echocardiographic contrast studies: Initial experience. Mayo Clinic Proc., 5/: 6.3 $(197.5)$

53. Ritter, D. G.: Contrast echocardiography: Peripheral vein injection of indocyanine green dee for detection and assessment of right-to-left intracardiac shumting Amcr. J. (ardiol.. 37: 171 (1976).

54. Silverman. N. H. French. J. W., Wallington, J., and Popp, R. L.: I:chocardiographic evaluation of the severity of valuar aortic stemosis in children. Pediat. Res., I0: $316(1976)$

55. Silverman N H. Lewis, A. B. Heymann, M. A., and Rudolph, A. M. Echocardiographic assessment of ductus arteriosus shunt in premature infants. (irculation. 50): $821(1974)$.
56. Solinger, R., Elbl, F., and Minhas, K.: Echocardingraphy in the normal neonate, Circulation, 47: 108 (1973).

57. Solinger, R. Elbl, F., and Mlinhas, $K$.: Deductive echocardiographic analysis in infants with congenital heart disease. Circulation, 50: 1072 (1974).

58. Valdes-Cruz. L. M., Pieroni. D. R., Roland, J. M., and Shematek, J. P.: Recognition of residual postoperative shunts by contrast echexardiegraphic techniques. Amer. J. Cardiol...37: 178 (1976).

59, Valdes-Cruz, L. M1. Pieroni, D. R., Roland, J. M. A., and Varghese, J. Echocardiographic detection of right-to-left shunts by peripheral vein injections. Circulation, 52: 121 (1975).

60. Vidne, B., Duszynski, D)., and Subramanian, S.: Pulmonary flow distribution in transposition of the great arteries. Amer. J. Cardiol.. 37: 178 (1976).

61. vonRamm, O. T., and Thurstone, F. L.: Cardiac imaging using a phased ultrasound system. 1. System design. Circulation, 53: 258 (1976).

62. Verdever, L. A., Creckmore, S. P., Schiller, N. B.: The measurement of systolic time intervals by echocardiography. J. Clin. Ultrasound, 2: 99 (1974).

6.3. Williams, D. E.. Sahm, D. J., and Friedman, W. F.: Cross-sectional ectocardiographic localization of sites of left ventricular outflow tract obstruction. Amer. J Cardiol. 37: 250) (1976)

64. Yabet S M lsabel-Jones, J., Bhatt, D. R. Nakazawa, M., Marks, R. A. and Jarmakani, J. M.: Echocardiographic determination of left atrial volumes in children with congenital heart disease. Circulation, 53: 268 (1976).

65. This research was supported by United States Public Health Service Grants HL 12373, HL 05846, and HL 17334.

66. Requests for reprints should be addressed to: W. F. Friedman, M.D., Chicf of Pediatric Cardiology, University Hosp̧ital, 225 West Dickinson St.. San Dicgo, Calif. 92103 (USA).

67. Received for publicition Junc 21. 1976.

68. Accepled for publication September 2, 1976
Alveolar macrophages differentiation lamellar myelin lysosomes

\title{
Maturation of the Rabbit Alveolar Macrophage during Animal Development. I. Perinatal Influx into Alveoli and Ultrastructural Differentiation
}

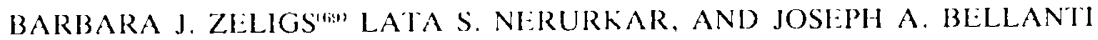 \\ Deparments of Pediatrics, Microbiology, and the Center for Interdisciplinary Studies of Immunology at \\ Georgetown, Georgetown University School of Medicine, W'ashington, D.C., USA
}

JOSEPH D. ZIELIGS

Laboratory of Molecular Biology, National Cancer Instimute, National Institutes of Health, Bethesda, Marylanci, USA

Summary

Rabbit alveolar macrophages (AM's) were collected by tracheobronchial lavage at sequential times during animal development. The total number of cells recovered by this technique was found to increase markedly shortly before birth (Fig. 4). This apparent influx of macrophages into the alveoli continued during the first postmatal week, and, at a reduced rate, throughout the first postnatal month of life (Fig. 3).

Ultrastructurally, ANI's of the prenatal period resembled their monocyfe precursors, and contained modest numbers of lysosomes and mitochondria, scant lamellae of ribosome-studded endoplasmic reticulum (RER), and a small Golgi apparatus (Fig. 12). A considerable amount of phagocytosed material was observed in these AM's, and consisted largely of cellular debris and two forms of surfactant-related phospholipids, termed tubular and lamellar myelin (Figs. 12-15). The quantity of these ingested phospholipids increased dramatically shortly after birth, in correlation with the known release of similar material from type II pneumocytes at this time. (Figs. 16 and 19).

During the first postnatal week ANI's showed a considerable increase in number of mitochondria and in the development of the RER and Golgi apparatus (Fig. 22). Increased accumulations of lipid droplets were also noted during this period. Ingested material continued to consist largely of surfactant-related phospholipids, but was less abundant at this time.

By 28 days after birth, AM's were nearly morphologically mature (Fig. 25). They showed large numbers of lysosomes and mitochondria, and well developed RER and Golgi apparatuses. Ingested phospholipid material was still visualized, and the in- 
complete degradation of this material appeared to give rise to the dense intraphagolysosomal whorls characteristic of the mature AM.

\section{Speculation}

The finding of a marked increase in lavageable $A$ NI's shortly before birth suggests that the initial influx of $\mathrm{AM}$ 's may serve to prepare the alveoli for early postnatal events. Possible factors which could contribute to the induction of this prenatal influx include hormonal stimulation involving estrogen and/or thyroid hormones, and chemotactic stimulation, possibly resulting from intra-alveolar surfactant.

The quantity of surfactant-related phospholipids ingested by A II's from all time periods studied suggests that scavenging of inactive and/or excess intra-alveolar surfactant may be an important homeostatic function of the AM1. Such a phospholipid scavenging role may be especially significant in the newborn animal when large quantities of surfactant are rapidly released into the alveoli.

There is now considerable evidence that macrophages are derived from precursor cells residing in the bone marrow $(8,20$, $58,63)$. These precursors are believed to give rise to circulating monocytes, which populate various tissues and finally differentiate into characteristic tissue macrophages. The environment of the macrophage appears to play a major role in this final differentiation process, accounting for the uniqueness of the various tissue populations.

In the lung, macrophage precursors appear to first populate the pulmonary interstitium $(7,8)$. Interstitial macrophages undergo division, and a population of these cells enters the alveoli $(7,8,60,61)$. Here, the final differentiation of the AM takes place in an environment of surfactant-related phospholipids, high oxygen tension, and inhaled particulate material. Fully differentiated macrophages in this environment are unique in several respects. Ultrastructurally, AM's show characteristic myelin-like whorls in their secondary lysosomes, which are not seen in other macrophage populations (42). In addition, significant differences have been described in $A M$ hydrolytic enzyme activities $(14,36)$, phagocytic metabolic pathways $(25,26,49)$, and resting oxygen consumption (25) when compared with macrophages in other environments.

The pulmonary enviromment, which appears to have such a profound influence on the final differentiation of the AM, undergoes dramatic changes in association with birth and during early postnatal development. It was therefore of interest to study AM's obtained from animals in the immediate perinatal period and in various subsequent periods. The present report describes and quantitates an influx of macrophages into the alveolar space, and depicts the ultrastructural characteristies of these AN's during the perinatal period and at later times in animal development. Subseguent communications will describe the biochemical characteristics, phagocytic function, and bactericidal capability of these cells $(40,64)$.

\section{MATERIALS AND METHODS}

\section{ANINIALS}

Alveolar macrophages were obtained from New Zealand white rabbits of both sexes (65). Groups of $10-100$ rabbits of each of the following ages were employed: 1 day before the expected date of birth; a few hours before the expected time of birth; 2, 6, and $20 \mathrm{hr}$ after birth; 4.7 . and 28 days after birth; 90 or more days after birth (considered adult).

Preterm deliveries were induced with 1 unit oxytocin (ParkeDavis) administered intravenously, or were accomplished by cesarean section, assuming a gestational period of 31 days. Maternal nesting activities on the 31 st day of gestation were used to determine the time of induction for rabbits of the few hours prenatal group.

\section{ISOLATION OF MACROPHAGES}

Rabbits were anesthetized with sodium pentobarbital, at a dosage of 5() $\mathrm{mg} / \mathrm{kg}$ body weight for adults, administered intravenously, and $5(0-150 \mathrm{mg} / \mathrm{animal}$ for the other age groups, administered intraperitoneally. Under sterile conditions a polyethylene cannula attached to a syringe was fastened into the trachea, and the heart and lungs were removed in toto. From this syringe, a volume of lavage fluid was slowly delivered into the trachea, and then gradually withdrawn. During this procedure, gentle massage was applied (37) over the entire lung surface to facilitate distribution of the fluid throughout the lungs and to help free the macrophages. Both the number of such lavage procedures performed per animal and the volume of fluid used for each lavage were found to affect the total cell yicld. Virtually all of the lavageable AM's were obtained by using $8-10$ lavages/ animal and results were optimal with volumes of $0.5,1,5$, and $30 \mathrm{ml} /$ lavage for animals from the perinatal, 4-7-day, 28-day, and adult time periods, respectively. The lavage fluid $\left(37^{\circ}\right)$ consisted of either sterile Krebs-Ringer phosphate, $\mathrm{pH} 7.2$, containing $200 \mathrm{mg} / 100 \mathrm{ml}$ glucose and $1.5 \mathrm{mM} \mathrm{Ca}^{++}$(KRP), or sterile $0.15 \mathrm{M} \mathrm{NaCl}$ solution. In contrast to the results of Brian and Frank in rats (9), these two lavage solutions resulted in statistically equivalent yields of cells.

The total yield of cells from animals of the perinatal time periods did not appear to be affected by the degree of lung expansion present. This was evidenced by the finding of statistically equivilent yields of cells from animals delivered by cesarean section and lavaged without breathing, and from animals of the same age which were induced by oxytocin and lavaged after breathing for a period of up to $4 \mathrm{hr}$, at which time the lungs are reported to be fully expanded (31).

After the lavage procedure, cell suspensions were kept at $\theta^{\circ}$ in polypropylene test tubes. Cell counts were made on aliquots from these suspensions to determine total cell yields. The cells in suspension consistently showed a viability greater than 95\%, as assessed by trypan blue exclusion.

\section{BACTERIAL CULTURES}

Just before lavage. swabs of the lower trachea were obtained for bacterial culture. Positive cultures were found only in some adult animals, and these animals were excluded from the present stucly.

\section{LIGHT MICROSCOPY}

Monolayers of cells were prepared from lavage suspensions for light microscopic examination. Lavalge suspensions were pelleted at $200 \times g$ and $4^{\circ}$, after which $10^{\circ}$ cells were resuspended in $0.05 \mathrm{ml} \mathrm{KRP}$ and incubated on Lab-Tek chamber slides (66), which were enclosed in a moist chamber for $30 \mathrm{~min}$ at $37^{\circ}$. To assess the phagecytic capability of the adherent cells, some of these monolayers were then incubated with $2-4 \times 10^{7}$ Staphylococcus aureus for 15 min with gentle agitation in the presence of $4 \%$ fresh adult rabbit serum. Monolayers were washed, methanol-fixed, and stained with $3 \%$ Giemsa solution for examination by light microscopy.

\section{ELECTRON MICROSCOPY}

Lavage suspensions were prepared for electron microscopy from 3-10 rabbits of each of the following ages: 30 days gestation (1 day prenatal); 2, 6, and 20 hr after birth; 7 and 28 days after birth; and adult. In order to obtain a sufficient quantity of cells for processing, suspensions from littermates of the perinatal periods (up to 20 hr after birth) were pooled. Suspensions were fixed for $1 \mathrm{hr}$ at room temperature in a solution containing $2 \%$ glutaraldehyde, $2 \%$ formaldehyde, and $0.02 \%$ trinitrophenol in $0.1 \mathrm{M}$ cacodylate buffer, $\mathrm{pH} 7.4$ (24). 
In a separate set of experiments the same fixative solution wats employed directly as the lavage fluid. This procedure did not appear to alter ultrastructural preservation, but did result in a decrealsed cell yich.

In other experiments, lavage suspensions were incubated with S. auretus at $37^{\circ}$ for 2 hr in the presence of $4 \%$ fresh adult rabbit serum before fixation. These preparations were used to assay the phagecytic cabability of the suspended cells.

Fixed suspensions were pelleted at $200 \times g$ and postfixed in $1 \%$ osmium tetroxide. The pellet was dehydrated with a graded series of ethanols and propylene oxide and embedded in Epon. Thick sections $(1 \mu \mathrm{m})$ were stained with toluidine blue for light microseopic examination. Thin sections were stained with uranyl acetate and lead citrate, and examined with an A.F.I. EM 6B or Philips 201 electron microscope. A total of approximately 400 electron micrographs of roughly median sections of $A M$ 's were analyzed. Estimates of eell size and of numbers of celfular organelles (mitochondria, lipid droplets, lamellac of endoplasmic reticulum, lysosomes, and Golgi complexes) were based upon measurements and counts made from these clectron micrographs.

\section{RESULTS}

\section{CFI.L. TYPES OBTAINED BY L.AVAGE}

Light microscopic examination of the cell suspensions obtained by lavage generally revealed homogencous populations of monomuclear cells. Suspensions from the perinatal time periods (up to $20 \mathrm{hr}$ after birth). however, did contain oceasional eryth- rocytes and desquamated squamous epithelial cells, as well as moderate quantities of extracellular material.

To determine whether the mononuclear cells observed were AM's, their phagocytic capability was tested, since this capability distinguishes AM's from nomphagocytic lymphocytes or epithelial cells $(22,34,61)$. Monolayers prepared from the lavage suspensions and incubated with $S$. aurens showed that virtually $100 \%$ of these glass-adherent cells, from all time periods. contained bacteria (Fig. 1). However, such glass-adherent cells might not have been representative of the entire population of cells in suspension. For this reason, lavage suspensions incubated directly with bacteria were also examined. One micrometer thick sections of these incubated suspensions revealed bacteria in the vast majority of cells (Fig. 2). Although such preparations showed occasional cells without bacteria, serial sectons revealed that many of these cells actually contained bacteria at other levels. It was therefore concluded that the vast majority of cells obtained by lavage were AMs.

\section{NUMBER OF AM'S LAVAGED FROM ANIMALS OF DIFFERENT AGIS}

The results of cell counts of AM's lavaged from animals of different ages appear in Table 1. together with corresponding lung and animal weights. It may be seen that the number of lavageable AN's increased dramatically during the perinatal period and throughout the first month of life. This is illustrated graphically in Figure 3, from which it is apparent that the most rapid increase in lavageable AM's per $\mathrm{g}$ of lung weight occurred during the first postnatal week. Figure 4 shows the details of the increase in AM's during the immediate perinatal period. It can

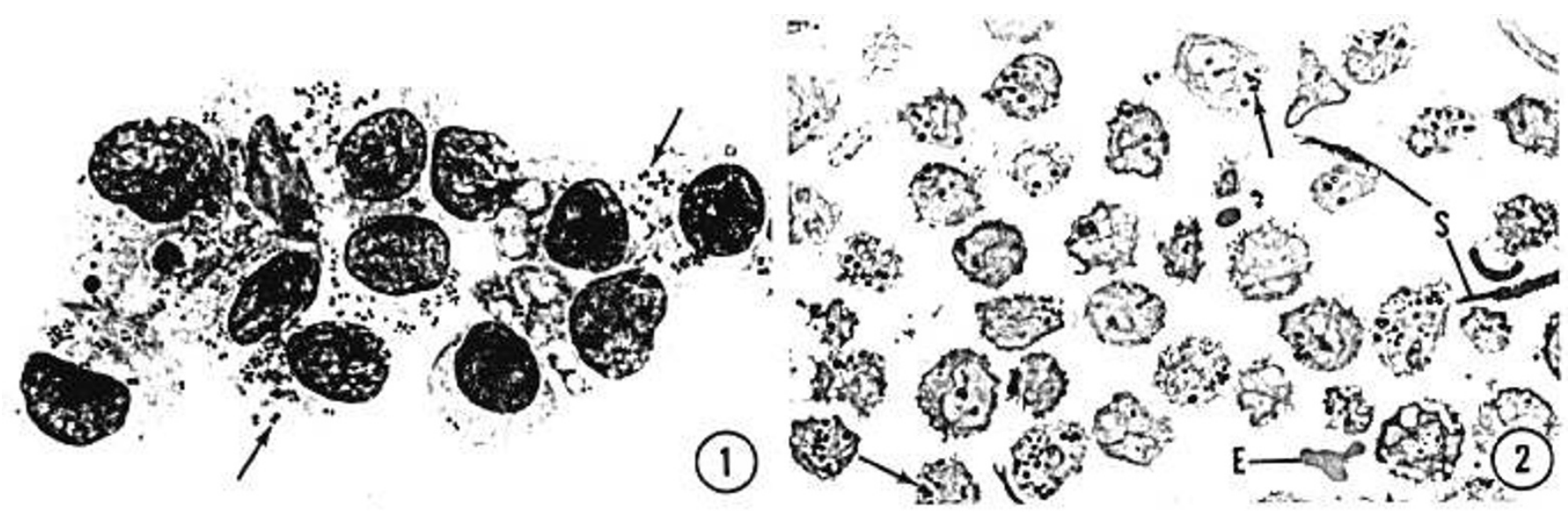

Fig. 1. Nomolayer of cells lavaged from a 2()-hr postnatal rabbit, incubated with Staphylococcus aureus. Numerous bacteria (arrows) have been ingested by each of these adherent cells. Giemsa stain, $x \quad 900$.

Fig. 2. Suspension of cells lavaged from a 2()-hr postnatal rabbit, incubated with Staphylococcus aurcus. Even though this section is only $1 \mu \mathrm{m}$ thick, ingested bacteria are apparent in the majority of cells (arrows). Squamous epithelial cells (S) (from the amniotic fluid) and erythrocytes (E) are also evident. Toluidine blue stain, $\times 90()$.

Table 1. Number of alveolar macrophages (AM's) lavaged from animals of different ages with corresponding lung and animal weights

\begin{tabular}{|c|c|c|c|c|c|c|}
\hline \multirow{2}{*}{ Age of animals } & \multirow{2}{*}{$\begin{array}{l}\text { No. of ani- } \\
\text { mals lavaged }\end{array}$} & \multirow{2}{*}{$\begin{array}{l}\text { No. of lit- } \\
\text { ters }\end{array}$} & \multirow{2}{*}{ Animal weight, $g^{\prime}$} & \multirow{2}{*}{ Lung weight, $g^{\prime}$} & \multicolumn{2}{|c|}{$\mathrm{AM}$ 's $\times 10^{\circ}$} \\
\hline & & & & & Per animal² & Per g lung weight ${ }^{2}$ \\
\hline 1 day prenatal & 25 & 3 & $44 \pm 9$ & $1.1 \pm 0.4$ & $0.04 \pm 0.01$ & $0.03 \pm 0.006$ \\
\hline Few hours prenatal & 20 & 2 & $45 \pm 8$ & $0.9 \pm 0.2$ & $0.18 \pm 0.03$ & $0.23 \pm 0.03$ \\
\hline 2 hr postnatal & 18 & 2 & $56 \pm 6$ & $1.0 \pm 0.2$ & $0.23 \pm 0.03$ & $0.25 \pm 0.04$ \\
\hline 8 hr postnatal & 101 & 15 & $52 \pm 8$ & $0.8 \pm 0.2$ & $0.54 \pm 0.04$ & $0.72 \pm 0.06$ \\
\hline 20) hr postnatal & 33 & 5 & $56 \pm 8$ & $0.9 \pm 0.1$ & $0.96 \pm 0.09$ & $1.1 \pm 0.1$ \\
\hline 4 days postnatal & 23 & 6 & $92 \pm 14$ & $1.2 \pm 0.3$ & $3.2 \pm 0.3$ & $2.6 \pm 0.2$ \\
\hline 7 day's postnatal & 88 & 16 & $116 \pm 33$ & $1.4 \pm 0.3$ & $5.0 \pm 0.3$ & $3.6 \pm 0.2$ \\
\hline 28 days postnatal & 27 & 12 & $456 \pm 135$ & $3.1 \pm 0.8$ & $24 \pm 2$ & $7.6 \pm 0.5$ \\
\hline $90+$ days postnatal & 13 & & $3.000 \pm 500$ & $13.7 \pm 4.5$ & $104 \pm 14$ & $8.2 \pm 1.3$ \\
\hline
\end{tabular}

1 Mean \pm SD.

2 Mean \pm SIEM. 

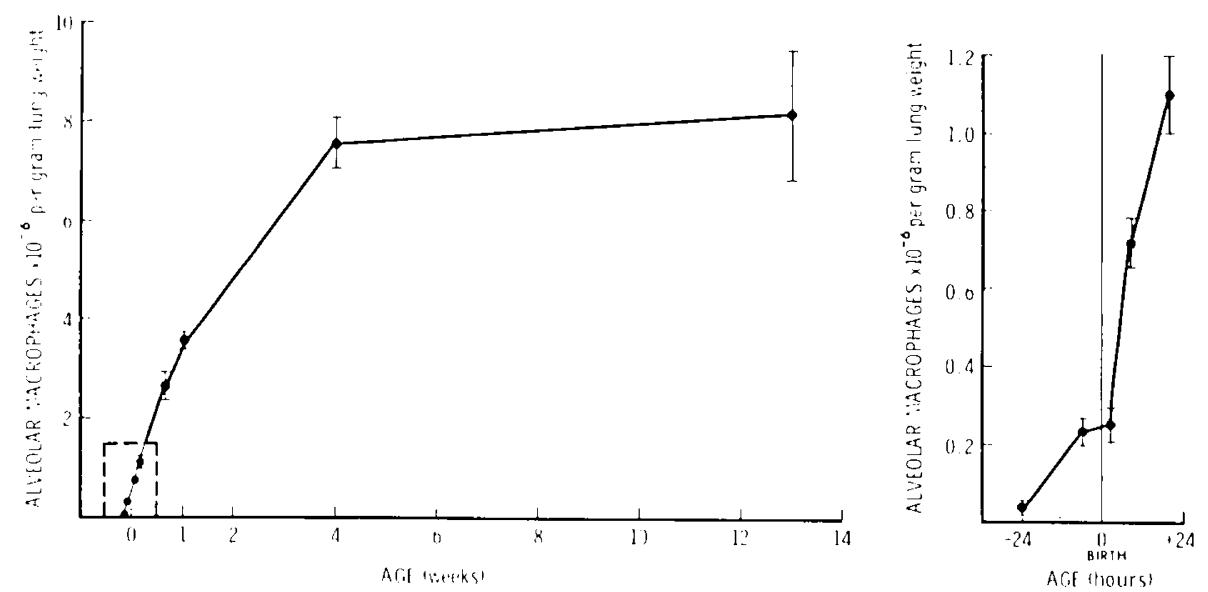

Fig. 3. Number of alveolar macrophages per g lung weight, lavaged from rabbits of different ages. Detail of the portion enclosed within the broken lines is shown in Figure 4. Values are expressed als mean \pm SEM.

Fig. 4. Number of alveolar macrophages per g lung weight, lavaged from rabbits during the perinatal period. Values are expressed as mean \pm SI:NI.

be seen that an increase in lavageable AMIs actually precedes animal birth by at least several hours.

\section{LIGHT MICROSCOPIC MORPHOL.OGY}

Perinatal Period. Nonolayers of ANIs from l-day preterm animals (Figs. 5, 6) characteristically revealed well spread cells with a rounded overall outline, and eceentric, oval nuclei. The cytoplasm was rather uniformly stained and contained occasional pale inclusions, usually measuring $1-2 \mu \mathrm{m}$ in diameter. These pale inclusions became progressively larger and more frequent postnatally, and were numerous in the majority of AM's by $20 \mathrm{hr}$ after birth (Figs. 7, 8). Rounded, hyaline, bleblike structures 1$4 \mu \mathrm{m}$ in diameter were also observed during the perinatal period, protruding from the spread cell surface. Nitotic cells, although uncommon, were occasionally observed in these preparations.

Seren Days afier Birth. Nonolayers from 7-day postnatal animals revealed an overall decrease in both the size and the frequency of pale cytoplasmic inclusions (Figs. 9, 10). In addition, a lightly staining region adjacent to the nucleus, in the central portion of the cell, was often apparent at this time. This region was several micrometers in diameter and was not sharply demareated from the remainder of the cytoplasm. Blebs were again observed at this time, and mitotic eclls were found with the highest frequency in these preparations.

Twenty-eight-day-old and Adult Animals. Monolayers from 28-day-old animals appeared to be similar to those prepared from adults. Pale cytoplasmic inclusions were only occasionally seen, but a lightly staining perinuclear region was usually apparent (Fig. 11). Cytoplasmic blebs were uncommon. Mitotic cells were rarely seen in adult AM's, but were observed in modest numbers in eclls from 28-day-old animals.

\section{HLLECIRON MICROSCOPIC MORPHOLOGY}

Thirty-day Gestation. AMls lavaged from 1-day preterm fetuses appeared to be a moderately homogeneous population of mononuclear cells. These cells were roughly circular in section, with a diameter of approximately $11 \mu \mathrm{m}$ (Fig. 12). The cell surface included numerous, rather pleomorphic folds or projections, and occasional pseudopods. The cytoplasm contained a modest complement of mitochondria and a small Golgi apparatus. RER was sparse and short, but free ribosomes were numerous. A modest number of medium density, $(0.1-0.4-\mu \mathrm{m}$, membrane-bounded granules (presumably lysosomes) were observed throughout the cytoplasm. Small coated and uncoated vesicles. $60-20() \mathrm{nm}$ in diameter, were also seen, associated with the Golgi apparatus or near the cell periphery. Intracytoplasmic lipid droplets were occasionally observed, most often in cells showing multiple phagocytic inclusions.

Phagocytic inclusions were frequently noted in AM's at this time, although considerable variability in the quantity and nature of inclusions were encountered from cell to cell. Two principal categories of inclusions were apparent. The first included phagocytosed cells or cellular debris (Fig. 12). Phagosomes containing large portions of recognizable cellular remnants (mitochondria, granules, nuckei) were frequently observed. The eell type which had been ingested could not ustally be determined. except in the casse of desquamated squamous epithelial cells. which could be readily recognized by their characteristic shape and fibrous density (sec Fig. 14). Such cells have been previously observed in ammiotic fluid (46), and presumably are carried into the fluid-filled alveoli by respiratory movements. The second category of ingested material appeared to consist of phagocytosed surfactant-related phospholipids (sec I)iscussion). Surfaceactive phospholipids are known to be released in large yuantities from type II pneumocytes in the perinatal period $(31,33,50)$. In the present study, two forms of apparent surfactant-related phospholipids were recognized during this period, and are referred to herein as tubular myelin (62) and lamellar myclin.

Examples of ingested tubular myelin were numerous in AM's from 1-day preterm fetuses, and were recognizable by their characteristic lattice-like meshwork (Fig. 12. inset; Fig. 13). Phagesomes containing this material usually measured $1-3 \mu \mathrm{m}$, and were associated with a homogeneous background matrix, from which the tubular myclin was variably distinct. In many instances structures were also observed which had a similar background matrix, but in which tubular myelin could not be visualized (Figs. 12, 14). Projecting from some tubular myelincontaining phagosomes were thin, membrane-bounded channels with contents resembling those of the phagosome (Fig. 12). Similar channels were also seen in the cytoplasm, often in the immediate vicinity of a phagosome.

Phagocytosed lamellar myelin was also common at this time, and was characterized as small osmiophilic whorls, composed of myelin-like lamellace interspersed with clear spaces (Fig. 12). Such material was often combined with tubular myelin within a single phagosome.

In addition to AMls. extracellular material was observed in moderate amounts in lavagates from the perinatal period. Such material corresponded closely to that observed within $A M$ 's, and consisted largely of lysed or degenerating cells. descuamated squamous epithelial cells, tubular myclin, and lamellar myelin (Fig. 15).

First Postnatal Day. Many changes in AM ultrastructure were already apparent during the first postnatal day. In the peripheral 

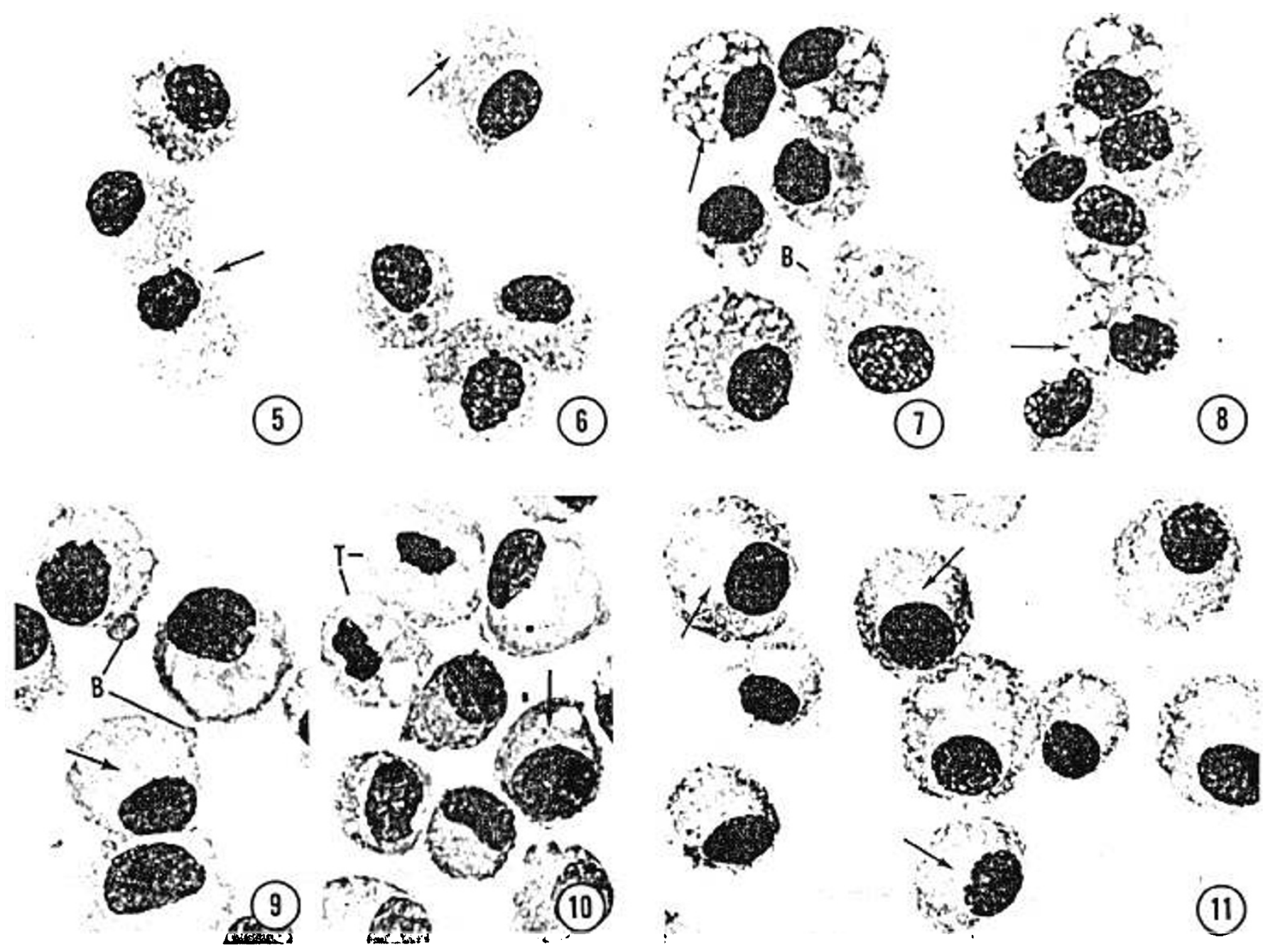

Figs. 5-11. Monolayers of alveolar macrophages lavaged from rabbits of different ages. Giemsa stain, $\times 9(0)$.

Figs. 5 and 6. Thirty-day gestation. These cells show rather evenly stained cytoplasm with occasional pale inclusions (arrows) and eceentrically placed nuclei.

Figs. 7 and 8 . Twenty hours after birth. A marked increase in the number and size of pale inclusions (compare with Figs. 5 and 6 ) is apparent (arrows). A rounded. hyaline, bleblike structure $(B)$ is seen projecting from one cell.

Figs. 9 and 10. Seven days after birth. Pale inclusions are less numerous and smaller in size by this time. A large, lightly staining region adjacent to the nucleus (arrows) can now be seen in many cells. Several blebs $(B)$ and a cell in mitotic telophase $(T)$ are also apparent.

Fig. 11. Twenty-eight days after birth. Pale cytoplasmic inclusions are seen only occasionally at this time, but lightly staining perinuclear regions (arrows) alre again evident.

cytoplasm. lamellac of RER were more developed, in both length and number, although they were rarely engorged or distended (Fig. 16). Intracytoplasmic accumulations of dense, $30-4()-n m$ diameter particles (presumably glycogen, which has been detected biochemically in adult AM's (29) ) were also increasingly evident, and were distributed throughout the cytoplasm, either singly or in multiparticle pockets (Fig. 16). Glyeogen pockets were frequently found in the immediate vicinity of lipid droplets, occasionally surrounding a particular droplet (Fig. 17). Lipid droplets had also increased somewhat in number and often showed a patchy deposition of stain over their peripheral portions. Small lysosomes were again noted at this time, but were less apparent in cells which had a large number of phagocytic inclusions. The cellular content of mitochondria was found to have decreased slightly from that observed in AM's from 1day preterm fetuses.

The quantity of surfactant-related phospholipids ingested by AMYs increased dramatically during the first postnatal day (Fig. 16). Whorls of lamellar myclin constituted the vast majority of this ingested material, and appeared to correspond to the pale inclusions seen by light microscopy. By $20 \mathrm{hr}$ after birth some lamellar myelin-containing phagosomes appeared to have fused with one another, resulting in large, 4-6- $\mu \mathrm{m}$, multiwhorl inclusions (Fig. 19). The electron density of these structures varied, sometimes within the same inclusion (Figs. 16, 19). Electrondense regions were observed to be highly osmiophilic in unstained sections, and had a myelin-like substructure (Figs. 18, 20).

An additional characteristic of occasional lamellar myclincontaining phagosomes was a peculiar, partially unravelled appearance (Figs. 16, 20, 21). Such phagosomes showed various degrees of separation or unravelling of some lamellac from the main myelin whorl. The separated lamellac were recognizable within thin, membrane-bounded channels (Fig. 20), which occasionally interconnected with one another, resulting in the formation of complex channel networks (Fig. 21). Ribosomes and glycogen particles were often evident in between these channels, suggesting that evagination of cell cytoplasm in between the myelin lamellac (either during initial ingestion of the lamellar myelin or at some later time) had produced this appearance.

Seven Days after Birth. A considerate number of ultrastructural changes were apparent in AM's at 7 days after birth, when 

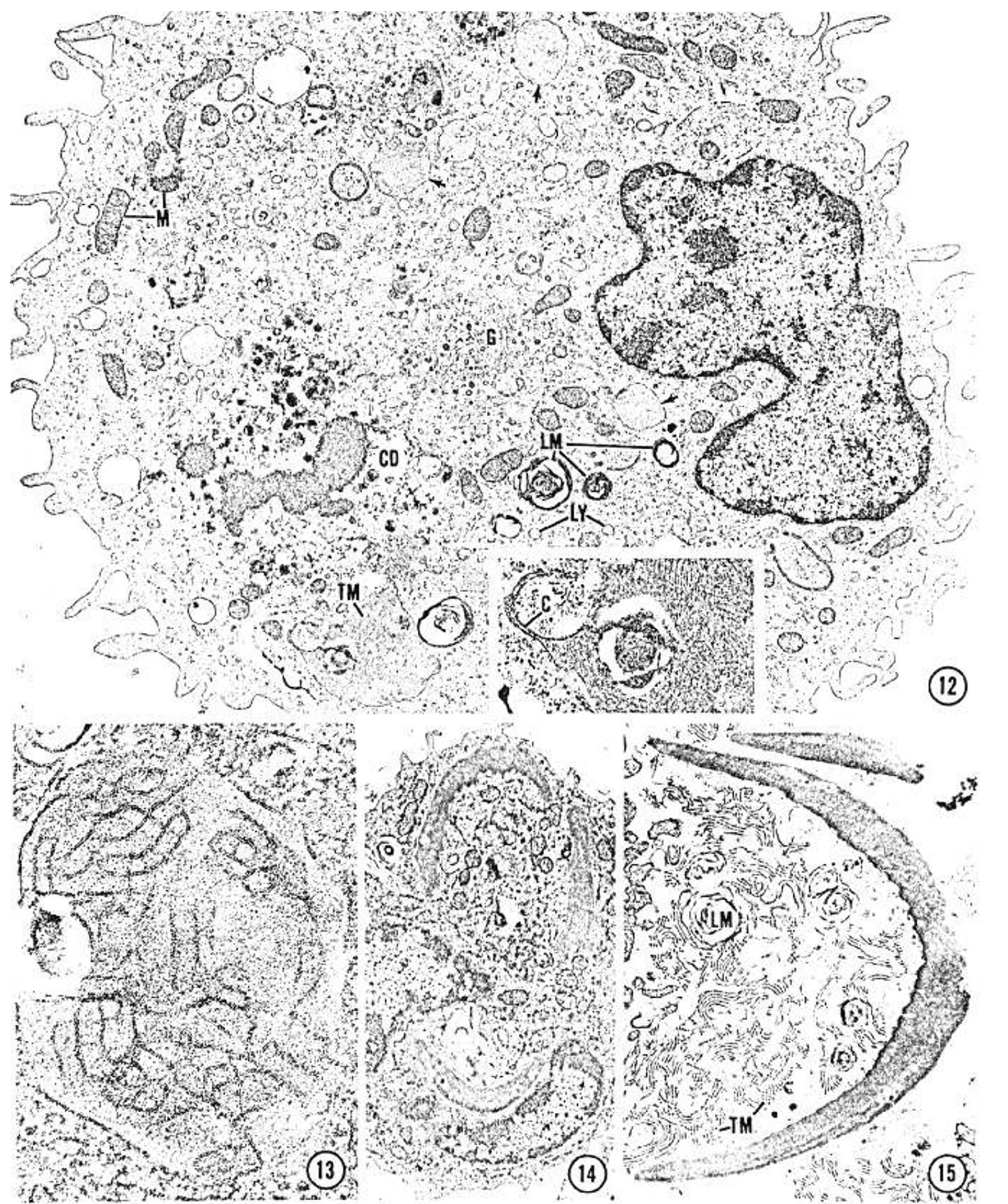

Fig. 12. Alveolar macrophage from a 30-day gestation fetus. The cell surface consists largely of irregular folds or projections. In the cytoplasm, a modest number of mitochondria $(M)$ and lysosomes $(L Y)$ are visible. Ribosome-studded endoplismic reticulum is sparse and short. A small Golgi apparatus $((j)$ lies near the eccentric, inclented nucleus. Scveral phagecytic inclusions are present. acluding a large portion of cellular debris $(C l))$. several small whorls of lamellar myelin $(L, M)$, and a phagosome containing tubular myelin (Thl) embedded in a homogenous matrix (sece inset). Inclusions having a similar matrix density, but latking recognizable tubular myelin are also present (arrows). Inset: Detail of the phageseme containing lubular myelin (sec also lïg. 1.3). An arched channel (c) projects from one side, $\times 12.2(10)$; inset $\times 29.000$.

Fig. 13. Another tubular myelin-containing phagosome. Roughly parallel unit membratne-like structures are separated by $30-50$ am, and are variably distinct from the hatheround matrix. $x \quad 90.000$.

Fig. 14. Alverlar macrophage from a 2-hr pestnatal amimal. Three large portions of descuamated squamous epithelial cells have been ingested. 7.800 .

lïg. 15. Ixtratcellular material from a 2 hour postmatal lavagate. Two portions of squamous epithelial cells, a mass of tubular myelin (TM), and scveral small whorls of lamellat myelin $(L, M)$ are depicted. $\times 11,200$. 


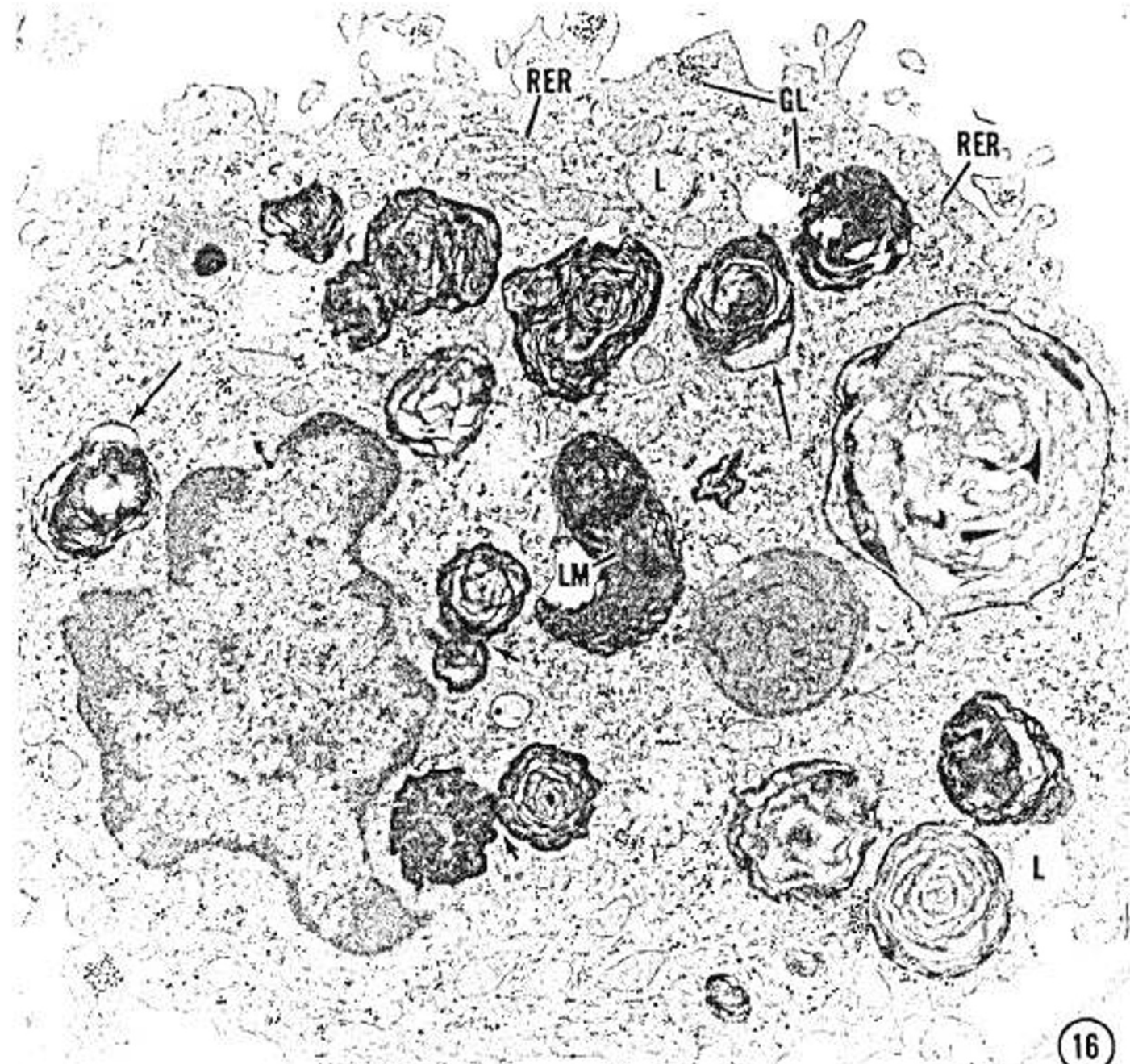

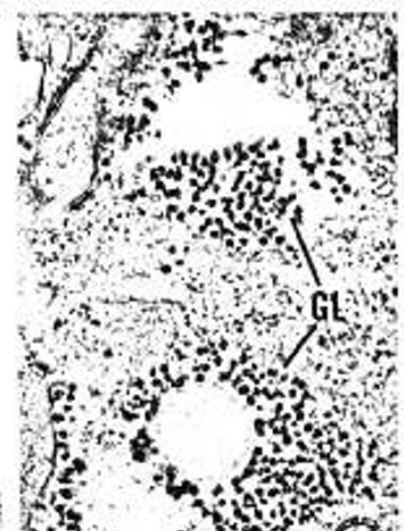

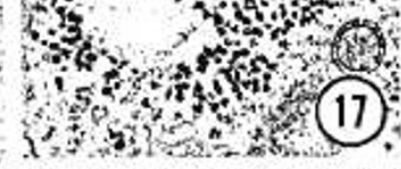

(16)
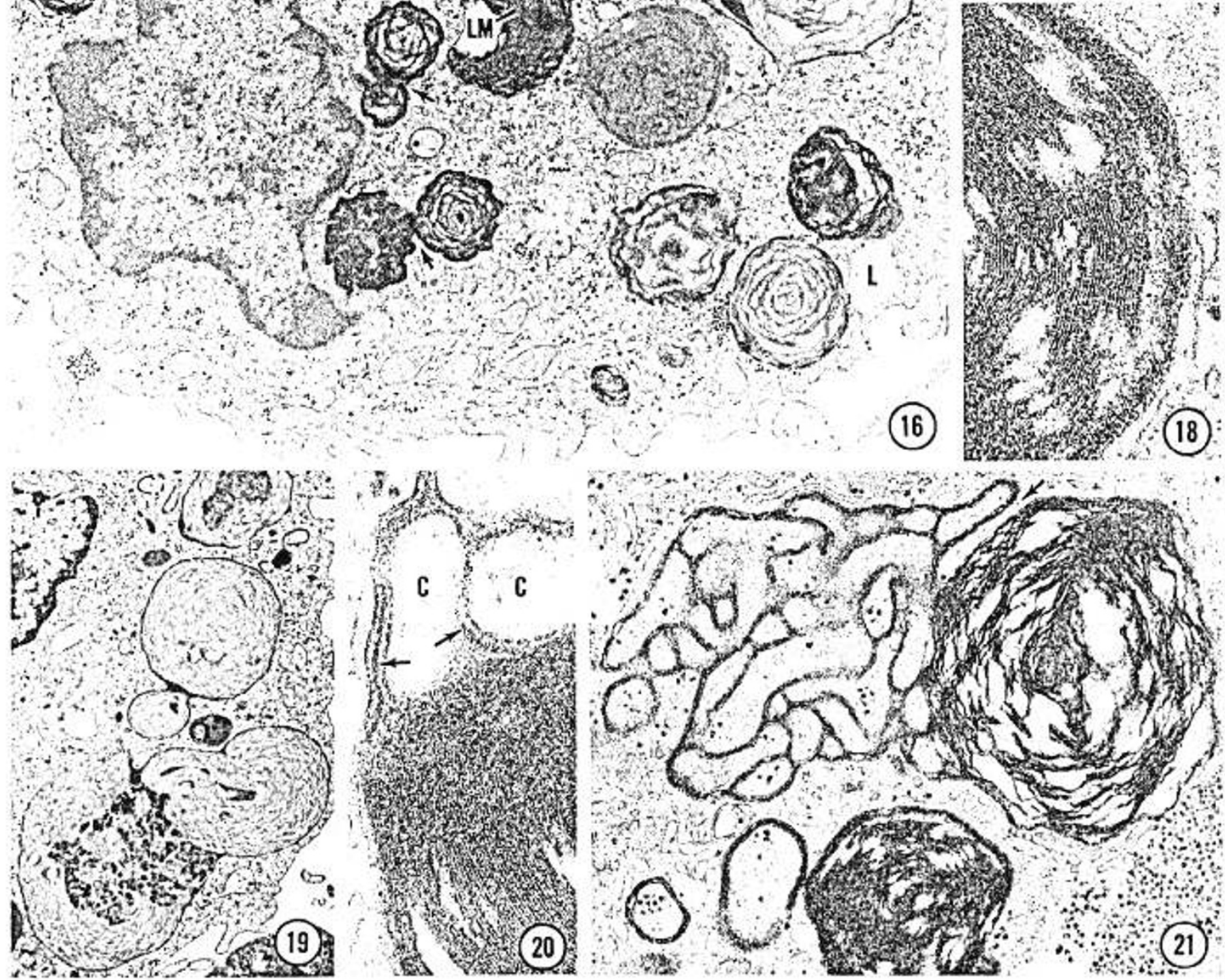

Fig. 16. Alveolar macrophage from a 6-hr postnatal animat. Ribosome-studded endoplasmic reticulum (RER) and intracytoplasmic glycegen deposits $(G L)$ are more prominent, and the quantity of phagocytic inclusions has increalsed markedly. Ingested material consists chiefly of lamellar myelin $(L, M)$ and varies somewhat in electron density. Possible sites of phagesome fusions are indicated (short arrows), and two lamellar myelin inclusions with a slightly unravelled appearance (long arrows) are shown. $\times 15,500)$.

Fig. 17. Examples of glecogen pochets $(G L)$ associated with lipid droplets are shown from a 6 -hr post natal alveolar macrophage. $x$ 27.700.

Fig. 18. Detail of a lamellar myelin whot. A 7.5-8.0-mm periodicity is visible. $\times$ 72.506

Fig. 19. Large multiwhorl lamellar inclusions with variable electron density from a 2(1-hr postmatal alveolar macrophage. These structures suggest phagosome fusions. $\times 9.100$.

Fig. 20. Detail of a partially unravelled lamellar myelin phagosome. Some lamellar material (arrows) appears within the thin, membrane-bounded channels which extend from the body of the phagesome. Cell cytoplasm (c) is found between the channels (see also Fig. 21). $\times \quad 76,500)$

Fig. 21. Lamellar myelin phatesome, with an extensively unravelled appearance. Multiple portions of cell cytoplasm (contatining glycogen particles) project between the myelin-containing channels. A site of possible cytoplasmic evatgination into the body of the myelin whorl is indicated (arrow). Detail of the smaller, more condensed phagosome is shown in Figure $18 . \times 25.500)$. 
compared with AM's from the immediate postnatal period (Fig. 22). Cell size had increased slightly, reaching an average diameter of $12 \mu \mathrm{m}$. In the cytoplasm, the Golgi apparatus was distinctly increased in size (Fig. 22). Counts of mitochondria revealed an approximate doubling in the frequency of this organelle compared with the immediate postnatal period. Lipid droplets were markedly more numerous and were somewhat variable in their electron density (Fig. 22). Glycogen particles were still associated with some lipid droplets, but were found less commonly at this time.

Although lamellar myelin-containing phagosomes which were similar to those of the carly postnatal periods were occasionally observed, most phagosomes at 7 days after birth appeared to be smaller and more electron dense (Fig. 22). These dense phagosomes were found to retain a myelin-like substructure (Fig. 22, inset), and appeared to represent lamellar myelin phagosomes whose contents had become condensed, with nearly complete loss of the interlamellar clear spaces typical of ingested lamellar myclin in the early postnatal periods.

Lysosomes were observed more frequently at this time, and images suggestive of lysosomal fusions with the dense phagosomes just described were frequently found. In the resulting phagolysosomes dense, lamellar myelin regions were often observed adjacent to less dense. presumably lysosomal, regions (Figs. 23, 24). In such instances a type of delamination process often appeared to be taking place. This process appeared to involve the separation of myelin strands of various widths from the dense region, so that they entered the lysosomal region (Figs. 23, 24). In the lysosomal region a variety of dense rings. whorls, and serpentine patterns were observed. Images suggestive of fusion and/or fission of other lysosomes and phagolysosomes with these regions were frequently observed (Fig. $23)$. Such processes appeared to account for small strands of myelin which were apparent in many phagolysosomes throughout the eell at this time (Figs. 22-24).

The yuantity of extracellular lamellar myelin and other extracellular material had decreased markedly by 7 days after birth, which correlated with the decrease in frequency of uncondensed lamellar myclin phagosomes at this time.

Twenty-eight Dass after Birth and Adults. The ultrastructure of $A M$ 's at 28 days after birth showed only a modest number of changes from that observed at 7 days. Cell diameter remained about $12 \mu \mathrm{m}$. In the cytoplasm, glycogen deposits were much less frequent, but mitochondria, lipid droplets, RER, and the Golgi apparatus remained prominent (Fig. 25).

Phagocytic inclusions were considerably less common at 28 days after birth, but both uncondensed and condensed lamellar myelin phagosomes were occasionally observed. Lysosomes and phagolysosomes were distinctly more numerous at this time, and were frecuently located around the periphery of the Golgi apparatus (Fig. 26). Phagolysosomes of ten contained strands of myelin, in various amounts and configurations (Figs. 25. 26). Such strands generally retained a lamellar substructure, but this was frequently less distinct and with a shorter periodicity than that observed in earlier time periods (Fig. 27). The delamination process first noted at 7 days after birth was again evident at this time, and appeared to account for the distribution of myelin strands to the mumerous small phagolysosomes.

The adult AM differed only modestly from that just deseribed. The RER and Golgi apparatus appeared somewhat reduced in size, and lipid droplets were found infrequently. Both uncondensed and condensed lamellar myelin phagosomes continued to be observed occasionally. Phagolysosomes were similar to those found at 28 days, exeept that they tended to be larger and more complex.

\section{DISCUSSION}

The results of the present study indicate that the number of lavageable AM's increases dramatically during the first postnatal week of life and continues to increase, but at a reduced rate throughout the first postnatal month. These findings correlate with previous histologic reports noting the patucity of observable AMls during the perinatal period $(21,30,32)$, and expand considerably upon previous preliminary quantitations of lavageable AM's during animal development $(41,55)$.

Of particular significance in the present study is the finding that an apparent influx of AM's into the alveoli actually precedes birth by at least several hours. Such a prenatal influx of cells may serve to prepare the alveoli for events of the carly postmatal period. At least two types of stimuli which could contribute to the induction of this prenatal influx seem worthy of consideration. The first is that of hormonal stimulation. Both estrogen and thyroid hormones have recently been reported to increase the number of lavageable AM's in adult rats (54), and serum levels of these hormones are known to increase markedly shortly before birth $(10,17,44,59)$. In addition, circulating estrogens have been found to be capable of inducing proliferation in some macrophages $(27,28)$, and an increased proliferation of cells in the alveolar interstitium (the site of $A M$ precursor cells) has in fact been observed shortly before birth (2). A second possible inductive mechanism for the prenatal influx of AM's is that of chemotaxis. Certain purified lipids and lipoproteins have recently been reported to be chemotactic for AM's (57). It therefore seems plausible that surfactant-related phospholipids which are released into the alveoli at this time may play a role as chemotactic agents.

After birth, the influx of AM's into the alveoli continues. The increased amount of intra-alveolar surfactant in the carly postnatal period correlates with the rapid influx of AM's at this time and again suggests the possibility of surfactant-induced chemotaxis. In addition, the postnatal influx of $A M$ 's may be related to the onset of breathing, and the consequent inhaled gaseous and/ or particulate material. Inhaled particulate material has in fact been shown to result in increased numbers of AM's in adult animals $(35,47)$.

The ultrastructural differentiation of the AM during animal development has not, to our knowledge, been previously described. In comparing the morphology of AM's lavaged from animals of different ages, it must be borne in mind that the same population of AM's is not being observed at each time period. Influx of new AMls as well as cell death occur, and hence the ultrastructural changes encountered in different time periods may reflect changes occurring in AN1 precursor cells as well as in the AM's themselves. In spite of this limitation, the present observations provide a number of insights into the pattern of differentiation of these cells and their interaction with the pulmonary enviromment. These observations bear some similarities to those previously reported during the transformation of monocytes into macrophages or during macrophage differentiation in other environments $(1,12,13,15,43,53,56)$. Paterns of changes noted in several organelles seem worthy of discussion.

\section{MITOCHONDRIA}

$A$ distinct increase in the number of mitochondria per $A M$ was found to oceur between 1 and 7 days after birth. This increase most probably reflects a changeover to a greater utilization of oxidative metabolism in these cells. Such a metabolic changeover is understandable in the pulmonary environment, and correlates with the known restriction of adult AM's to an oxidative metabolism to meet their phagocytic energy requirements (25).

\section{GLYCOGLN}

A decline in $A M$ glyeogen stores was observed during the first postnatal week, followed by a further decline during the remainder of the first postnatal month. This may represent a depletion of energy stores, in AM's, and/or in their precursor cells, consequent to metabolic stresses of the early postnatal period. Alternatively, this decline may be at least partially the result of glycogen utilization in the production of lipid stores which 


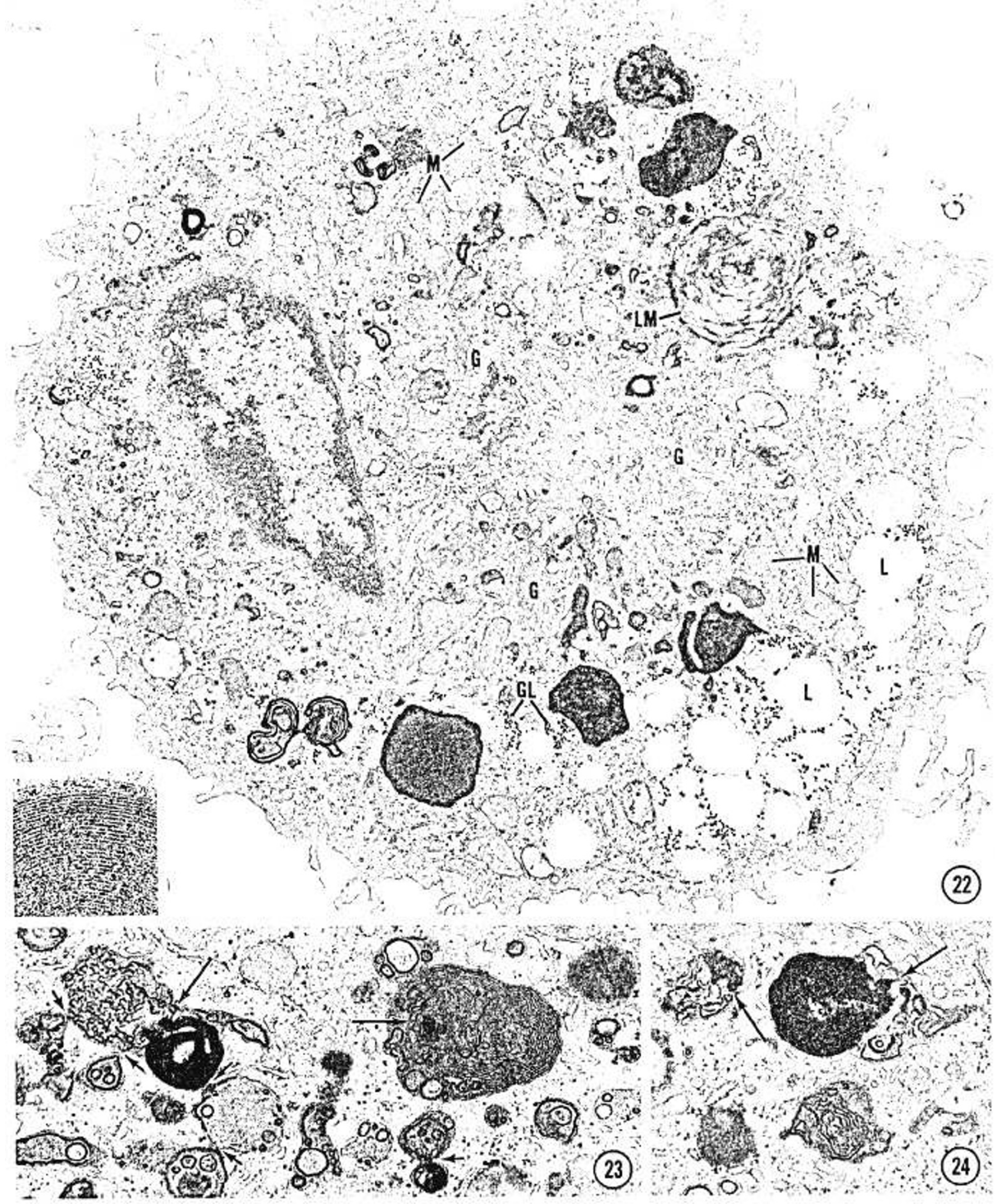

Fig. 22. Alveolar macrophage from a 7-day postnatal animal. The Golgi apparatus $(G)$ is more prominent and mitochondria $(M)$ and lipid droplets $(L)$ are more numerous than in the immediate postnatil period. Glycogen particles $(G L)$ are associated with some lipid droplets, and are somewhat more abundant in this cell than usual at this time. Although one typical lamellar myelin-containing phagosome ( $L M /$ ) is apparemt, most inclusions are now quite dense and consist of tightly packed myelin (see inset). Inset: Detail of a dense inclusion. A myelin-like substructure is evident and shows a 7.2-nm periodicity. $\times 14,(00)$; inset, $\times 100,000$

Figs. 23 and 24. Detail of phagolysosomes from a 7-day postnatal alveolar macrophage. In places (long arrows) the dense myelin structures appear to be undergoing a delamination process, resulting in the production of thin myelin strands. These strands may become distributed ansong the cellular phagolysosomes by repeated fusion and fission processes. Possible sites of fusion or fission are indicated (short arrows). Fig. $23 \times 30,000 ;$ Fig. 24 30.200. 


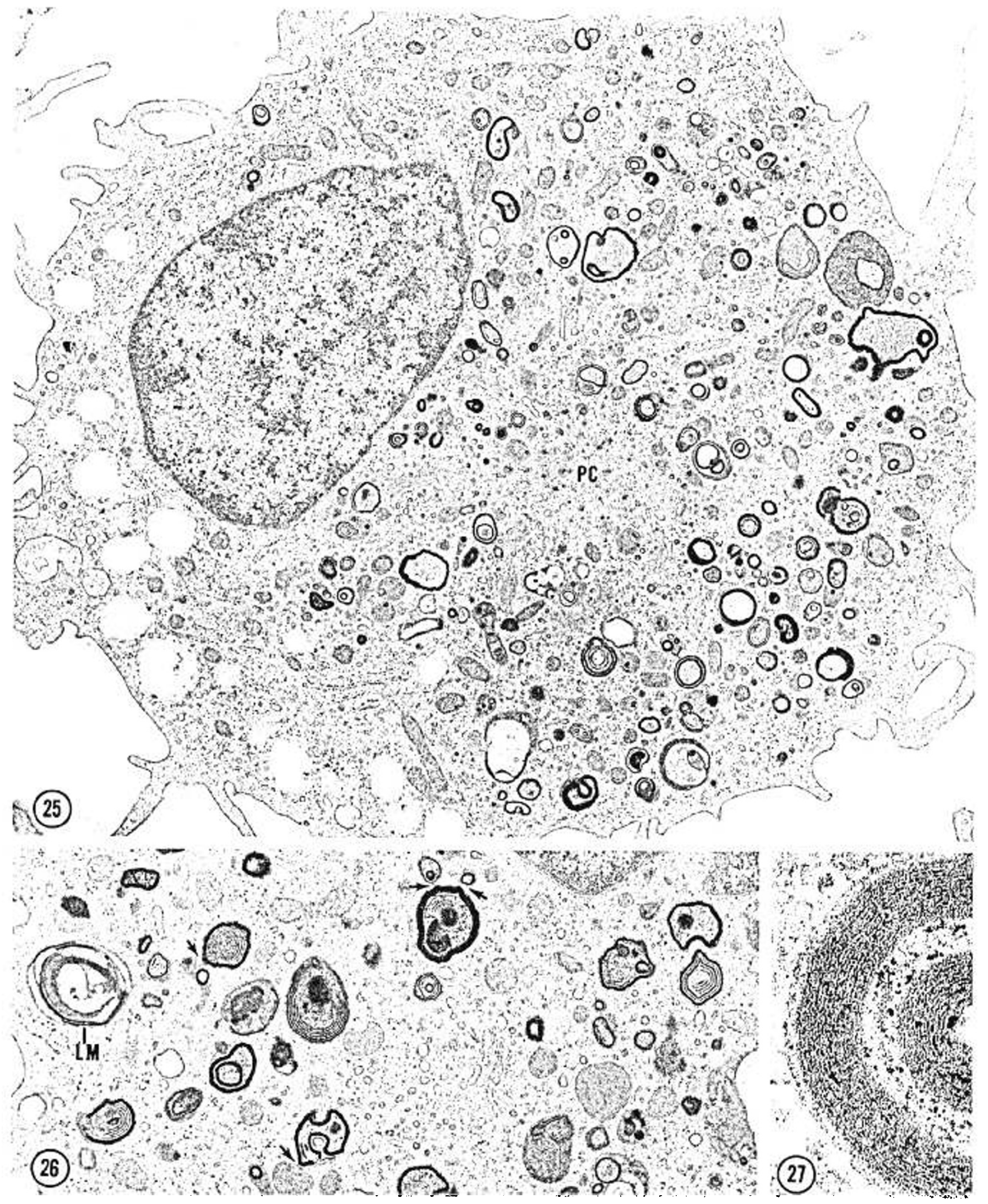

Fig. 25. Alveolar macrophage from a 28-day postnatal animal. The (solgi apparatus, ribosone-studeded endeplasmic reticulum, mitochondria, and lipid droplets remain prominent but glycegen deposits are no longer visible. Lysosomes athd phagolysosomes are locatted around the Golgi region, and are much more numerous at this time. They contain varying amounts and configurations of myelin strands. A number of microtubules radiate from the pericentriolar region $(P()$, imparting a certain ratdial organization to the aldjacent organclles, $x \quad 13,000$.

Figg. 26. Cytoplasmic granules from a 28 -day postnatal macrophage. Nost granules contain dense strands of lamellar melin residue and hence presumably represent phagolysosomes. Possible sites of fusion or fission between phagolysosomes are indicated (arrons). A lannellar myelincontaining phagesome is also present $(L . Y) \times 20,300$.

Fig. 27. Detail of intraphagolysosomal myclin strands from a 28 -day postnatal macrophage. A lamellat periodicity of $5-6$ nm is evident in the two strands depicted. $\times 133,000$. 
increased considerably during the same period. This possibility is strengthened by the close association of some lipid droplets with glyeogen pockets which was observed in the present study, and by at relationship between glycogen deposition and lipid production which has been demonstrated by biochemical technigues in both fetal adipose tissue (39, 52), and fetal lung (5).

\section{I.IPII) DROPLIETS}

An increased accumulation of intracytoplasmic lipid droplets was observed in A.M's at 7 and 28 days after birth. There are at kast the possible explanations for this accumulation. The first is that these dreplets result from lipid synthesis via the utilization of glyeogen stores, as described ahove. The second is that the lipid dreplets may derive at least in part from the degradative products of ingested surfactant. Which consists largely of phospholipids. The abundance of lipid droplets at 7 days would then reflect the large yuantity of phospholipids taken up during the carly postmatal period. A third possible explanation for the accumulation of lipid droplets may be related to the ingestion of maternal milk, which has a high lipid content, and on which newborn rabbits feed for approximately 1 month. Hyperlipidemia has in fact been documented in infant animals of several species, and has been directly alssociated with the lipid content of maternal milk (18). Furthermore, experimemally induced hyperlipidemias have been shown to result in similar lipid accumulations in AMls and in their precursor cells $(3,4)$.

\section{RI:R. (IOL(II APPARAIUS, ANI) LISOSOMIIS}

An increase in both the length and number of RER lamellate was noted during the first postmatal day followed by increased development of the (jolgi apparatus between the ist and 7 th postnatal days. Increased development of the Golgi apparatus may account for the lightly staining perinuclear region first observed during the same time peried in monolayer preparattions. In addition, increased development of the RIER and (jolgi apparatus may be preliminary $t o$ an accelerated production of lysosomes, which were observed in increased numbers in subseguent periods, and which are beliced to be produced by these or related organclles $(42,45)$. The distribution of lysosomes around the periphery of the Golgi apparatus supports the contention that the originate in this region. A similar lysosomal distribution has been observed in other macrophages (12).

\section{PHAGOSOMI:S AND PIAGOLYSOSONILS}

It is cleat from the present observations that $A N$ 's. from all periods examined are highly phagocytic cells. Ingested material Was found to consist largely of tubular and lamellar myelin. Such material was often obsersed in AMls from 1-day preterm fetuses, but became increasingly evident in AMls shortly after birth. By $20 \mathrm{hr}$ after birth, this material was abundant in the majority of $\mathrm{AM}$ s. This timing for the ingestion of tubular and lamellar melin by AN's coincides closely with the reported timing for the relcase of surface-active material from type II pnecumocytes into the alveoli $(31,3.3)$. Furthermore, the ultrastructure of released material is essentially equivalent to that of lamellar medin (50). Tubular myelin. although it does not ciirectly resemble the material rekiased from type II pueumecves, may be produced from lamellar myelin in the alveolus (5) under the proper lipid-water conditions (31). In addition, structures which appear to be morphologically identical with tubular and lamellar myelin have been isolated and characterized from adult rat lung homogenates (termed tubular and "common" myelin (19. 23)) and appear to be highly active in reducing surface tension and to consist largely of phospholipid. Similarly, biochemical studies of the AM's employed in the present investigation revealed a marked increalse in the phospholipid content of these cells in parallel with the increased tubular and lamellar melin ingestion observed morphologically (40) Collectively, these findings strongly suggest that the tubular and lamellar myelin observed in AM s of the present study represent ingested surfactant-related phospholipids. Which derive from type II pnemocytes.

The yuantity of phospholipid material ingested by $A M$ 's of all time periods studied suggests that surfactant uptatie may be a normal function of the A.M. Such a function would correlate with previously reported examples of tubular or lamellar myelin ingestion by addult ANS, under both normal $(6,+2)$ and pathological $(11,48.51 .01)$ conditions. In addition, biochemical (38) and histochemical (61) evidence for phospholipid uptake by adult $A M$ 's has appeared, and has similarly prompted the suggestion that these cells may play a role in the clearance of spent or excess surfactant $(38,+2)$. This kind of phospholipid-scavenging role may be especially important in the newborn animal, when large yuantities of surfactant are rapidy released into the alveoli.

The degradative patterns asseciated with ingested surfactantrelated phospholipieds are also of interest. Tubular myclin appeared to undergo a relatively rapid degradative process, resulting in the production of homogeneous, medium density inclusions. Lamellar melin, on the other hand, appeared to undergo a mere prolonged and probably incomplete degradative process. This process appeared to invole the interaction of lysosomes and phagolysosomes with ingested lamellar melin, resulting in the separation of strands of myclin from the lamellar myelin whorl. By repeated fusion and fission processes, such as are believed io be characteristic of lysosomal structures (16), these separated myclin strands then appeatred to become distributed among the cellular phagolysosomes, accounting for the varjous patterns of dense intrapliugely sosomal strands or whorls characteristic of the mature AM.

It had been suspected for some time that the intraphagolysosomal whorls of the mature AM represented undigested plospholipid material. Several possible sources of this phospholipid material had been suggested, including membranes from ingested cellular debris (12), membranes from antophagocytosed cellular material (12), and phagocytosed surfactant (42). The present observations strongly suggest phagocytosed surfactant as the source of this phospholipid material. and point specifically to ingested lamellar myelin as the forerumer of the dense intraphagolysosomal whorls. This derivation woukd also account for the fact that such whorls are a characteristic finding only in macrophages associated with the pulmonary enviromment.

\section{(ONCLUSION}

Rabbit Ail's lavaged from animals of varying ages were studied. (2uantitation of the AM's recovered revealed an apparent influx of macrophages into the alveoli, which began shortly before birth, and which continued throughout the first postnatal month of life. The morphologic maturation of $\mathrm{AM}$ 's and the interation of these cells with the pulmonary environment were also examined during animal development. Of particular significance was the finding of quantitites of ingested surfactant-related phospholipids in AMIs from anmals of all ages. This finding supports the contention that AM's may play an important role in the scavenging of inactive and/or excess intra-alvedale surfactant.

Note alded in Proof. While this manuscript was in press two papers have appeared which also support the concept of AM's as surfactant scavengers: Nichols, B. A.. J. Exp. Med., 1f4: 906 (1976); Golde, D. W. e et al., Ann. Int. Med. 85: 30.4 (1976).

\section{RIFIERIEN( ISS ANI) NOIISS}

1. Adams. 1). ().: The structure of mononeclear phagecytes differentiating $i n$ vive. 1. Sequential fine and histolegic studies of the effect of bacillus (almeltc-Gucrin (BCG). Amer. J. Pathol., 76: 17 (1974).

2. Adamson, 1. Y. R., and Bowden, D. H.: Derivation of type 1 epithelium from type 2 cells in the developing rat lung. I.ah. Invest.. 32: 7.36 (1975).

3. Bernick. S.. and Alfin-Slater, R. B : Pulmonary infiltration of lipid in essential fatty-atcid deficiency. Arch. Pathol.. 75: 1.3 (14)6.3).

4. Bernick. S.. and Patck, P. R.: Eeffect of cholesterol feceling on rat reticuloendothelial ststem. Arch. Pathol. 72: 7R (1961). 
5. Blackburn, W. R., Logstem, P. A., Akxander, J. A.. and Delli-Bove, J.: Correlations between glyongen and lecithin levels in developing fetal lung after various hormone injections. Pediat. Res.. 10: 458 (1976).

6. Bowden. D. H.: The alveolat macrophatge. Curr. Topics Pathol.. 5.5: 1 (1971).

7. Buwden. I). H., and Adamson. I. Y. R.: The pulmonary interstitial cell as immediate precursor of the alveolar macrophage. Amer. J. Pathol., 68: 521 (1472),

8. Bowden, D. H., and Adamson, I. Y. R., Grantham, W. G.. and Wyatt, J. P.: Origin of the lung macrophage: Evidence derived from radliation injury. Arch. Pathol. s8: $540(1969)$.

9. Brain, J. D., and Frank, R.: Alseolar macrophage adhesion: Wash electrolyte composition and free cell yicld. Amer. J. Physiol. 34: 7.5 (1973).

11. Brown, J. B.: Urinary excretion of oestrogen during pregnancy, litetation, and the re-ciablishment of menstruation. Lancet, $i: 704$ (1956).

11. Cohen, A. B.. and Geczy, D).: Purification of two populations of human alveolar matrophages from surgical specimens. Amer. Rev. Resp. Dis.. 108: $972(1973)$

12. Cohn, Z. A.: The structure and function of monecyles and macrophages Advan. Immunol., 9: $16,3(1968)$

13. Cohn, Z. A., and Bensen, B.: The differentiation of monenuclear phagecstes: Morphology. cytochemistry. and hiochemistry. J. Fxp. Mad., 121: 153 $(196,5)$.

14. Cohn, Z. A., and Weiner, E.: The particulate hedrolases of macrophages. I. Comparative enzymolegy, isolation and propertics. J. Ixp. Ned.. //8: v91 $(1963)$

15. Dannenberg, A. M.. Ander, M... and Shima, K.: Matcrophage accumulation. division, maturation, and digestive and microbicidal capacities in tuberculous lesions. III. The turnover of macrophages and its relation to their activation and antimicrobiat immunity in primary B. C. (3. Iesions and these of reinfection. J. Lmmunol.. /109: 1109 (1972).

16. De.Duve, C... and Wattiaux, R.: Functions of lysosomes. Ann. Rev. Physiol., $28: 435(1966)$.

17. Fisher, I). A.. Dussault, J. H. Hohel, ( . J., and Lam, R.: Serum and thyroid gland triigdothyronine in the human fetus. J. (lin. Enderrinol. Netab., 36: 307 (1973).

18. Greenberg, L. D., and (innzalez, I. I..: Influence of fatty acid composition of infamt formula on development of atrleriosclerosis. Ixp. Nolec. Pathol. lo: $240(1969)$.

19. (iil, J., and Reiss. (). K.: Isolation and characterization of lamellar bodies and tubular myelin from rat lung homogenates. J. (cill Biol. .58: 1.52 (1973)

20. Godleshi, J. J., and Brain, J. 1).: The origin of alveolar macrophages in mouse radiation chimeras. J. Ixp. Med., 1.36: 6.30 (1972).

21. Heilman, D. H.: In vitro toxicity of enchetexin for matrophages of young guinca pigs and rabbits. Int. Arch. Allergy, 33: $501(1968)$.

22. Hippleston, A. (i., and Young, A. L.: Uptake of incrt particulate matter by alveolar cells: An ultrastructural study. J. Pathol. / /l: 159 (197.3)

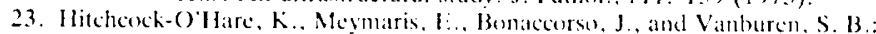
Separation and partial charactcrisalion of surface-active fractions from mouse and rat lung homogenates. J. Histochem. Cytochem.. 24: 487 (1976)

24. Ito. S.. and Karnowsky, M. J.: Formaldehyde-glutaraldehyde fixatives containing trinitro compounds. J. (cll Biol.. 39: 168 a $(1968)$

25. Karmovsky. N. L.: Mctabolic basis of phagocytic activity. Physiol. Rev., 42. $143(1962)$.

26. Karnowsky, M. L.. Simmons, S., Glass, I. A.. Shafer, A. W.. and D'Arey Hart, P.: Metabolism of macrophages. In: R. van Furth: Mononuclear Phagocyles, p. 117 (Blackwell Scientific Publications, ()xford. 1970)

27. Kelly, L. S., Brown, B. A., and Dobson, E. L.: (c)ll division and phagecytic activity in liver reticulo-endothelial cells. Prex. Soc. Ixp. Biol. Med.. Ilo $555(1962)$.

28. Kelly, L. S., and Dobson. L. L.: Fvidence concerning the origin of liver macrophages. Brit. J. Exp. Pathol.. 52: 88 (1971)

29. Khandwala, A. S... and Gec. J. B. L.: Factors in glucose oxidation by alveolar macrophages: Glucose tramsport and glycogemolysis. (hest, 67: oris (1975)

30. Kiktatwa, Y.: Morphology and morphologic development of the lung. In: I: M. Scarpelli: Pulmonary Physiology of the Fetus, Newborn and Child, p. 37 (Lea \& Febiger, Philadelphia, 1975).

31. Kikkawa, Y., Mlotoyama, E. K... and Gluck, L.: Study of the lungs of fetal and newborn rabbits: Morphologic, biochemical, and surface physical development. Anker. J. Pathol.. 52:177(1968).

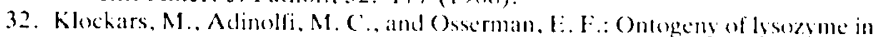
the rat. Proc. Soc. Bxp. Biol. Med.. 145: $6(1)+(1974)$.

3.3. Krasno, J. R., Knelson, J. H., and Dallderf. F. G.: (hanges in the alveotar lining with the onset of breathing. Amer. J. Pathol., $60: 471$ (1972).

34. Kuhn, C : Cytechemistry of pulmonary atveolar epithelial cells. Amer. J. Pathol., 53: $809(1908)$

35. LaBelle, C. W., and Bricger, H.: Patterms and mechanisms in the climination of dust from the lung. In: ( N. Deavies: Inhaled Particies. p. 350 (Pergamon Press, L.ondon, 1961)

36. Leake, E. S., Gonzalez-Ojeda, D., and Myrvik, O. N.: Enzymatic differences between normal atveolar macrophages and oil-induced peritoneal macrophages obtained from rabbits. Exp. Cill. Res.. 33: 553 (1964).

37. Myrvik, $Q$. N., Leake, E. S. and Fariss. B.: Studies on pulmenary alveolar macrophages from the normal rabbit: $A$ lechnique to procure them in a high state of purity. J. Immunol. 86: $128(1961)$
38. Namark, A.: Collular dynamies and lipid metabolism in the lung. led. Proc., 32: $1967(1973)$

39. Napolitano, L., and Fawectt. D.: The fine structure of brown adipose tissue in the new born mouse and rat. J. Biophys. Biochem. (ytol.. 4: 085 (1958).

40. Nerurkar, L... Zeligs, B. J., and Bellanti, J. A.: Maturation of the rabbit alveolar macrophage during animal development. II. Biochemical and enzymatic changes. (In preparation.)

41. Nerurkar. L.. Zeligs. B.. Peters, S., and Bellanti. J. A.: Developmental studies of lysosomal and respiratory enzymes of the rabbit alveolar macrophige. J. (cill Biol. 67: 306a (1975).

42. Nichols, B. A.: Phatgocvtosis and degradation of surfactant by alveolar macrephages. J. Cell Biol., 67: 307a (1975).

43. Nichols. B. A., and Bainton, D. F.: Differentiation of human monocytes in bonc marrow and blood: Sequential formation of two granule populations. Lab. Invest., 24: 27 (1973).

44. Nicol. T.. Bilbey, D. I. J.. Charles. I. M. Cordingley, J. L., and VernonRoberts, B.: Oestrogen: The naturat stimulant of body defense. J. Endecrinol.. 30: $277(196.4)$

4.5. Novikeff, P. M., Novihoff, A. B.. Ouintana, N., and Hauw, J.: Golgi apparatus, GERL. and lysosomes of neurons in rat dorsal root ganglia, studied by thich section and thin section cytochemistry. J. (c.ll Biol. .50): 859 (1971).

46. Nory, M. J., Portman, (). W.. and Bell, M.: Evidence for pulmonary and other sources of amnotic fluid phospholipids in the rhesus monkey. In: $C$. A. Vilke, D. B. Villec, and J. Zucherman: Respiratury Distress Syndrome, p. 205 (Academic Press, New York, 1973).

47. Pratt, S. A., Finley, T. N.. Smith, M. H., and Ladman, H. J . A comparison of alveolar macrophages and pulmonary surfactant(?) obtained from the lungs of human smokers and nonsmokers by endobronchial lavage. Anatt. Rec. 16.3: $497(1969)$.

4S. Pratt, S. A.. Smith. M. H., Ladman, A. J.. and Finley, T. N.: The ultrastiucture of alveolar macrophages from human cigarette smokers and nonsmokers. Lab. Invest., 24: 331 (1971).

49. Rossi, F., Zabucchi, G.. and Romeo, 1).: Metabolism of phagocytosing mononuckar phagecytes. In: R. van Furth: Mononuckar Phagecytes, p. 4.41 (Blackwell Scientific Publications, ()xforcl, 1975).

50. Ryan, U. S.. Ryan, J. W.. and Smith, D. S.: Alvolar type H cells: Studies on the mode of release of lamellar bodies. Tissue (ell, 7: 587 (1975).

51. Schaffiner, F., Folig, P. Trachtenterg. I.. Structure of rat lung after protracted oxygen breathing. Arch. Pathol. 83: 99) (1967).

52. Shafrir, E., Shapiro, B., and Wertheimer. E.: Glycogen metabolism in adipose tissue. In: A. E. Renold and G. F. Cahill: Handbook of Physiology, Vol. 5: Adipose Tissue, p. 313 (Americin Physiological Society, Washing(on. 1). (.. 190.5$)$

53. Schmalzl, F., Ilubner, H., Asamer. H.. Abbrederis, K., and Braunsteiner, H.: Cytochemical and immunohistological investigations on the source and functional changes on momonudear ecll in shin window exudate. Blood, 34 $129(1969)$.

54. Schorn. H.. and Euratom, C. W.: Some hormonal effects on alveolar phagocytosis in the rat. J. Reticulocondethel. Soc.. 18: 35:a (1975).

55. Sieger, L.. Attar, H. (Okada, I)., and Thibeault. D.: Alveolar macrophages (A.M.) in rabbit and human fetuses and neonates. J. Reticuloendothel. Soc.. 18: 47b (1975)

56. Sutton, J. S., and Weiss. 1.: Transformation of monocytes in tissue culture into macrophages, epithelied cells, and multinucleated giant cells: An clectron microscopic study. 3. (c)ll Biol., 28: 303 (1966).

57. Tainer. J. A. Turner, S. R.. and I.ynn, W. S.: New aspects of chemotaxis: Specific target-cell attraction by lipid and lipoprotein fractions of tischericha coli chemetactic factor. Amer. J. Pathol., 81: 401 (1975).

58. van Furth. R.: Origin and kinetics of monocytes and macrophages. Sem. Hematol. $7: 125(1070)$

59. Vernon-Roberts, B. (1:d).: The Materophage, p. 108 (Cambridge University Press, Cambridge. Fngland, 1972)

60) Vijeyaratnam. G. S., and Corrin, B.: Pulmonary histiocytosis simulating descuatmative interstitial pneumonial in rats receiving oral iprindole. J. Pathol., /08: 105 (1972)

61. Vijeyaratnam, (B. S., and Corrin, B.: Origin of the pulmonary alveolar macrophage studied in the iprindole-treated rat. J. Pathol. 108: 115 (1972).

62. Weibel. B. R.. Kistler. G. S., and Töndury. G.: A sterolegic efectron micror scope study of "tubular myclin figures" in alveolar fluids of rat lungs. $Z$ Zellforsch. Mikrosk. Anit., 64: $418(1966)$.

6.3. Weiden, P. L.. Storb, R., and Tsoi, M.-S.: Aarrow origin of canine alvedar macrophages. J. Reticulecondothel. Soc., 17: 342 (1975).

6.4. Zeligs, B. J., Nerurkar, L. S., and Bellanti. J. A.: Naturation of the rabbit alveclar macrophage during animal development. III. Phagocytic and bactericidal function. (In preparation.)

6.5. B and H Rabbitry. Rochville, MJ.

66. Miles Laboratoric's, Naperville, Ill

67. The authors wish to thank Dianc Hargrave for her assistance.

68. This rescatrch was supported by National Institutes of Health Grant HL16748 .

69. Requests for reprints should be addressed to: B. J. Zeligs, Department of Pediatrics. Georgetown University School of Medicine, 3800 Reservoi Ru.. Washington, D.C. 20007 (USA)

70. Reccived for publication Junc 23, 1976 .

71. Accepted for publication September 9, 1976. 